\title{
OBSERVATIONS ON CHYTRIDIACEOUS PARASITES OF PHANEROGAMS. XXV. PHYSODERMA JOHNSII SPARROW, A PARASITE OF CALTHA PALUSTRIS L. ${ }^{1}$
}

\author{
Frederick K. Sparrow \\ Department of Botany, University of Michigan, Ann Arbor 48104
}

\begin{abstract}
A B S T R A C T
The morphology of the endobiotic and epibiotic stages of Physoderma jolmsii Sparrow on Caltha palustris is described. Highly characteristic of the endobiotic stage is the formation of numbers of large, narrowly pyriform cells with a tuft of rhizoids at the broader (distal) end. Early developmental features are not included since germination of the resting spore has not as yet been achieved. Reasons for maintaining this taxon distinct from older ones on Caltha palustris are given.
\end{abstract}

IN 1961 I briefly described and diagnosed as Physoderma johnsii a fungus found by the late R. M. Johns and myself at several localities in the vicinity of the Biological Station of the University of Michigan at Douglas Lake. Somewhat earlier, the epibiotic stage of this parasite had been found in the field (Sparrow and Johns, 1959). Three localities were cited in the first paper, namely, Hebron Mud Creek Swamp, Lancaster Lake and the mouth of the Maple River on Burt Lake. Searches in recent years for the Caltha parasite have been almost completely unsuccessful owing to modifications of the aforementioned sites. One leaf, bearing some infection was retrieved in 1974 from a dwarf plant at the Lancaster Lake locality from a repeatedly mowed lawn! The present paper gives an expanded, illustrated, and slightly amended account of this fungus, combining the epibiotic stage found earlier, and the endobiotic one, primarily from the 1974 collection.

In explanation of the above, it will be recalled that species of Physoderma are obligate parasites and consist of two entirely separate and distinct plants. The endobiotic plant (Fig. 2) is strongly polycentric and bears on its extensive rhizoidal system peculiar enlargements termed "turbinate cells," and thick-walled, brownish resting spores. The latter germinate, usually after overwintering in the decayed host, and produce typical posteriorly uniflagellate zoospores, each with a colorless globule. From our observations these zoospores can form new endobiotic systems, or epibiotic stages on new host plants. The epibiotic stage is confined to a single cell of the host, perches on the outside of the epidermal cell and produces inside a short bushy clump of rhizoids. The whole structure at maturity reminds one of a monocentric chytrid such as Rhizophydium

${ }^{1}$ Received for publication 28 April 1975.

Acknowledgment is made to the National Science Foundation (Grant GB-3333) for support of this project.
(Fig. 11). Its zoospores resemble those produced by the resting spores but are generally slightly smaller, and bear a colorless or sometimes orangecolored globule. They, like the R.S. ("resting spore") zoospores, may form new endobiotic plants or epibiotic ones.

Host sYMPToms-It is primarily the leaves which are attacked, although infections are occasionally found on the inflorescence axes and even on the maturing fruits. On the leaf lamina (primarily the lower surface) Physoderma produces at first lead-colored, later brownish-lilac, or cinnamon-colored, eventually black, round to elongate, slightly raised, occasionally acervuluslike pustules, $0.5-1.0 \mathrm{~mm}$ wide. These may be scattered but are frequently found concentrated along the main veins, especially near the junction with the petiole (Fig. 1). Concentrations may also occur along the edges of the laminal undersurface. Infections on the petiole tend to be more elongate.

ENDoBiotic STAGE-A highly characteristic feature of this species, marking it off from other congeneric forms on Ranunculaceae, is the complexity of its endobiotic system. This is wellshown in Fig. 2-4. As may be seen, the strongly polycentric thallus consists of an extensive system of rarely branched, somewhat rigid, delicate rhizoids upon which are formed somewhat ovate "turbinate cells" which are often divided into several compartments by delicate membranes (Fig. 2a). These structures are common to all Physodermas and may vary somewhat in shape and number of compartments. Occasionally, in Physoderma johnsii they bear a tuft of short rhizoids at the broader end, either sessile or at the tip of a slender prolongation (Fig. 1b). These cells may also produce extensive rhizoidal outgrowths on which additional turbinate cells may form. 


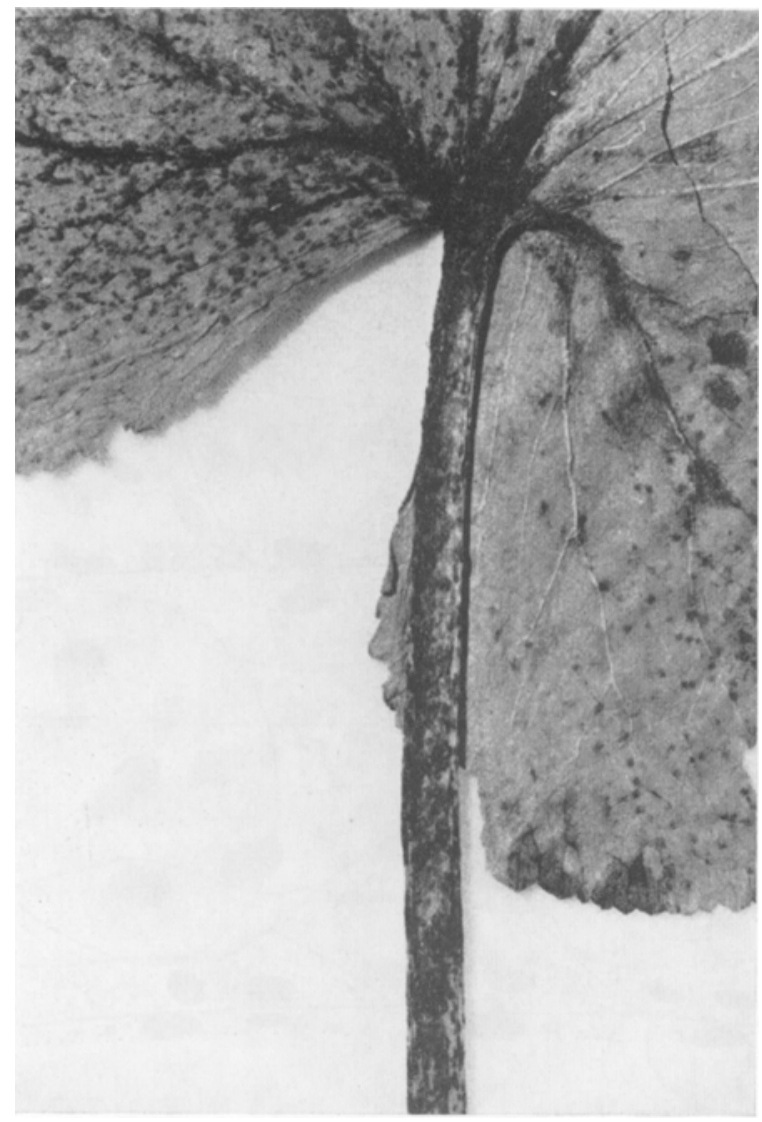

Fig. 1. Physoderma johnsii on Caltha palustris. Portion of underside of infected leaf showing dark areas of infection especially along veins and extending onto the petiole.
In young infections, long, unbranched rhizoids are often seen to terminate against the face of a cell wall of a newly invaded host cell in small ovate bodies bearing distal tufts of short rhizoids (Fig. 3b). These bodies enlarge and elongate into narrowly pyriform, very distinctive unsegmented structures as illustrated in Fig. 2c, 4a, reminiscent of those found in the Physoderma on Myriophyllum (Sparrow, 1974). As may be seen in Fig. 2c they sometimes seem to arise from a tufted, segmented turbinate cell. The cysts seen in Fig. 4b appear to be young turbinate cells proliferated from the larger structure. Inability to secure germination of the resting spores of the parasite as well as seeds of the host has made impossible developmental studies like those of other species of Physoderma. Paradermal sections of infected material have been relied upon and the sequence of development inferred from these. Owing to inevitable displacements of the delicate parts, this method has obvious limitations. What is considered an early stage in the development of the parasite is shown in Fig. 6. Here two large, elongate tufted pyriform structures, one of them divided into two compartments, are producing at the tips of narrow tubes new tufted bodies which presumably function as haustoria in the host cell, as possibly did the parent cells. Whether the tube elongates first and then forms secondary turbinate bodies or elongates after such bodies are formed is not known. From a study of the fragments of thalli shown in Fig. $2 b, 3 b$, c, the first alternative seems most likely.

Resting spores arise as ovoid bodies at the tips of conspicuous tubular outgrowths from both compartmentalized turbinate cells (Fig. 3d) and from

Fig. 2, 3. Caltha cortical cells infected with Physoderma. 2. At a, is a cluster of ovate, septate turbinate cells; $b$, is a tufted segmented cell, gives rise at $c$ to one of the large tufted, narrowly pyriform cells characteristic of this species; $d$, a cluster of small cells, possibly young stages of pyriform cells shown at e; f, an immature nearly full-sized resting spore with two haustorial outgrowths visible; g, several young tufted turbinate cells which have arisen at the tips of unbranched rhizoids emanating from a collapsed structure in the upper host cell. Displacement of delicate parts by the cutting process is evident in these and following sections. 3. a, small segmented untufted turbinate cell; $b$, a cluster of very young, probably tufted pyriform, turbinate cells terminating unbranched rhizoids. The large turbinate cell at $\mathrm{c}$ is divided into compartments, the basal one of which has given rise to tufted rhizoidal axes and new turbinate cells. At d. mature resting spores are shown which have clearly been formed as outgrowths of non-tufted segmented turbinate cells. All $\times 825$.

Fig. 4-12. Endobiotic and epibiotic stages of Physoderma in Caltha. 4. Endobiotic structures of fungus. a, 3 tufted, pyriform turbinate cells, the one in the lower host cell very long; $b$, a tufted turbinate cell on the lower surface of which are 3 younger cells; c, a maturing resting spore rudiment produced at the tip of a tubular outgrowth from a tufted unsegmented turbinate cell. The nearly mature resting spore at $\mathrm{d}$, bears numerous outgrowths as does the younger one just above it. 5. A mature resting spore still attached to its turbinate cell. Many of these are found floating free in mounts of infected host sections. 6. Two pyriform tufted turbinate cells (one segmented) which appear to be giving rise to secondary ones.-Fig. 7-12. Epibiotic stages.-Fig. 7-10. Young stages in epibiotic sporangium development. These structures are resting on the outside surfaces of the host epidermal cells. 7. shows the upper thick-walled cyst of a portion of the expanded zoospore; within the host cell is a cluster of rhizoids arising from a minute apophysis. 8. Top view showing somewhat slipper-shaped outline. 9, 10. Smaller examples like 7. 11. Side view of discharging sporangium showing gibbose aspect, folds in wall of sporangium, posteriorly uniflagellate zoospores emerging through wide basal pore, and endobiotic cluster of rhizoids. 12. Formation of secondary sporangium. All $\times 825$. 


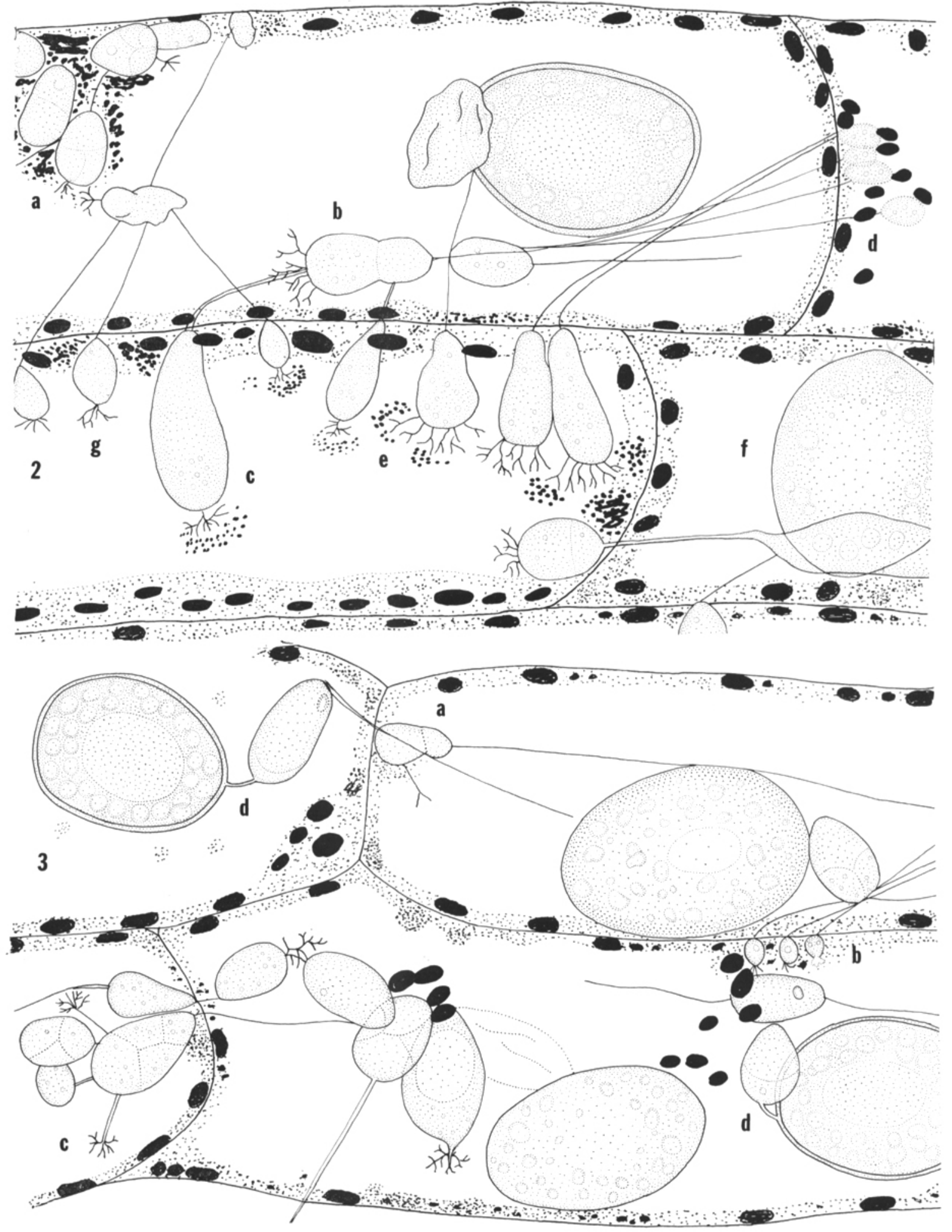




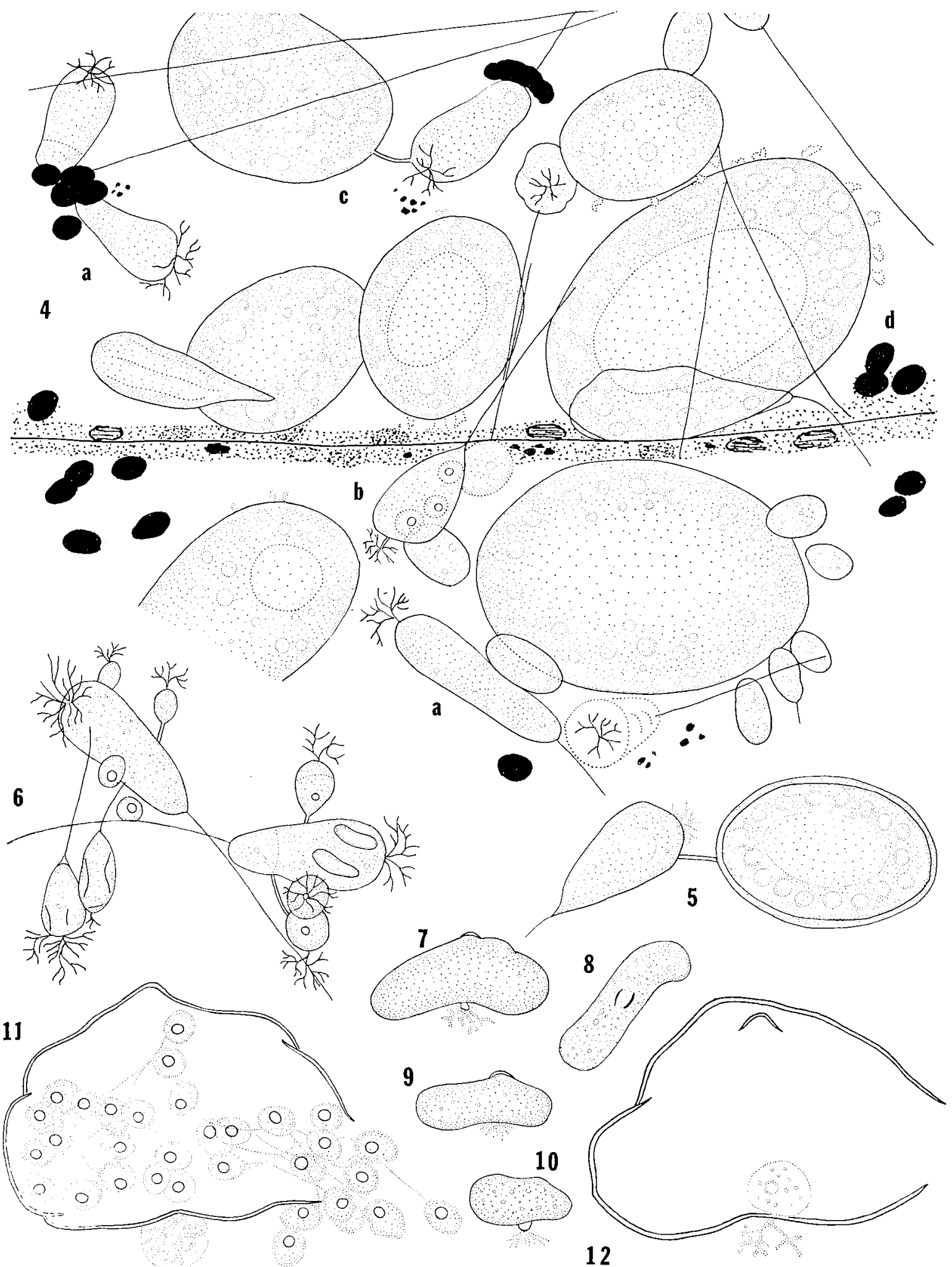


the large elongate pyriform structures (Fig. 4d, 5). As enlargement proceeds, the contents of the young resting spore rudiment undergo a series of changes precisely like that described in various other Physodermas (Sparrow, 1964, for example) and need not be repeated here. As the spore approaches maximum size, the wall steadily thickens and becomes golden to amber. Its contents, bearing numerous globules, become disposed around a large, central vacuolar structure. At full maturity, resting spores are ellipsoidal and somewhat flattened on one face (Fig. 5). As many as seven may be seen crowded into a single cortical cells of the host. They are $27.2-38.4 \mu \mathrm{m} \times 17.6-30.4 \mu \mathrm{m}$, the wall being $1.5-2 \mu \mathrm{m}$ in thickness. Occasionally tufts of antler-like outgrowths may be seen on their surface. In study preparations resting spores are frequently seen detached from the rhizoidal system but still attached to the parent cell (Fig. 5).

Inability to germinate these resting spores has been mentioned but work is continuing on this important aspect of the life cycle. It is reasonable to suppose that a finger-like sporangium is formed upon the dehiscence of a cap of wall material and that posteriorly uniflagellate zoospores are eventually liberated from this sporangium. ${ }^{2}$ Certainly this is the sequence in other Physodermas known.

Epibiotic stage-In field-collected material, this stage occurs in some abundance, particularly on the petioles and stipules (see Sparrow and Johns, 1959). Sporangia are also present on the lamina but are difficult to discern. Youngest stages seen are depicted in Fig. 7-10. Here, in both top and side views, there is clearly seen on the somewhat slipper-shaped body, the cap-like, thick-walled, unexpanded portion of the cyst of the zoospore from which the sporangium has arisen. This cyst has clearly been moved upwards by the vertical enlargement of the sporangium rudiment which has also expanded in a bilateral fashion beneath it. ${ }^{3}$ In side view the sporangium is somewhat gibbose and ridged and there may also be seen the bushy tuft of rhizoids which often arises from a small apophysis which lies below the location of the cyst (Fig. 7). The sporangia are epibiotic on single host epidermal cells.

During maturation, a series of characteristic protoplasmic changes takes place precisely like that described in other Physodermas ( $P$. maculare, Sparrow, 1964, for example). At full maturity, sporangia are $40-50 \mu \mathrm{m}$ long by $20-28 \mu \mathrm{m}$ in greatest diam. A single $10-\mu \mathrm{m}$ broad basal discharge papilla is formed and within the sporangium a number of zoospores are cleaved out, each bearing a single large colorless globule. Dis-

\footnotetext{
${ }^{2}$ Recently verified and a few epibiotic sporangia produced. Resting spore zoospores are $5 \mu \mathrm{m}$ in diam.

3 The cyst was erroneously stated (Sparrow, 1961) to be opposite the papilla.
}

charge (Fig. 11) is achieved upon the deliquescence of the papilla and the rapid discharge of the posteriorly uniflagellate zoospores, $5 \mu \mathrm{m}$ in diam. These are temporarily immersed in the material of the papilla before individually swimming away. Secondary sporangia are formed by "internal proliferation," i.e., by renewal of growth at the base of sporangia (Fig. 12), a process which may be repeated. several times. Interestingly, on these new sporangia there is often visible a humplike apical protuberance corresponding in position with the unexpanded portion of the cyst wall found on the primary sporangium.

Discussion-It was at first thought that the Physodermas on Caltha found at the several sites possessed individual differences in host symptoms induced and in their resting spores sufficient to recognize them as distinct taxa. Continuous observations on host symptoms (shape of pustule, color, etc.) in the greenhouse, however, made it clear the infections underwent a series of changes during maturation of the resting spores. Sizes of the latter showed slight individual differences only; certainly at present the sizes of resting spores are not sufficient to be considered of taxonomic importance. All possessed the same elaborate endobiotic system. They are now believed to relate to a single taxon.

Two other species have been described from Caltha palustris, namely, Physoderma bohemicum Saccardo (1914) and P. calthae Bucholtz (1916). In addition, several European investigators have identified Physodermas on Caltha with Schroeter's (1885-1889) collective species, $P$. vagans, namely Krieger ("Fungi saxon." No. 1537), Sydow ("Phyco. et Protom" No. 180), Vestergren ("Micro, rar. select." No. 200-b; No. 714) and Lagerheim (in herb., Germ. Feldsee in Baden, Aug. 1887). Nothing is known about any of these European fungi except for their resting spores. Quite obviously no further elucidation of their morphology, particularly details of their endobiotic system and epibiotic sporangia, will be forthcoming from their authors. It seems futile to apply an earlier name in an attempt to identify them with the more fully known $P$. johnsii. Indeed, it is entirely possible when more is known about the host range of Physodermas, changes in morphology on different host, etc., that $P$. johnsii itself will be shown to be allied and even identical with some earlier-named, well-described species. A recent study of morphology and host range of a Physoderma on a closely related host, Ranunculus septentrionalis (Sparrow and Saunders, 1974), indicates morphological differences in the two Physodermas. Chief of these is the lack in the Ranunculus parasite of the narrowly pyriform, tufted turbinate cells. The epibiotic stage, however, is nearly identical and the resting spores nearly the same size, those on Caltha being some- 
what larger $(27.2-38.4 \mu \mathrm{m} \times 17.6-30.4 \mu \mathrm{m}$ compared with $26.25-35.0 \mu \mathrm{m} \times 19.25-28.0 \mu \mathrm{m})$. Results of cross-inoculation experiments are considered inconclusive. Using the Ranunculus parasite zoospores as inoculum, three trials involving 11 Caltha plants were carried out with negative results. No reciprocal crosses could, of course, be made.

\section{LITERATURE CITED}

Bucholtz, F. 1916. Materials for a mycological investigation of Russia 8: 6 (in Russian).

Saccardo, P. A. 1914. Notae myologicae. Series xviii (V. Fungi Bohemici). Ann. Mycologici 12: 295-297.

SCHroETER, J. 1885-1889. Cohn. Kryptogamen-Flora von Schlesien Die Pilze Schlesiens 3(1): 1-814.

Sparrow, F. K. 1961. Observations on chytridiaceous parasites of phanerogams. $X$. Notes on some species of Physoderma occurring in the Douglas Lake region of Northern Michigan. Papers, Mich. Acad. Sci., Arts, Letters 46: 183-194.

. 1964. Observations on chytridiaceous parasites of phanerogams. XIII. Physoderma maculare Wallroth. Arch. Microbiol. 48: 136-149.

. 1974. Observations on chrytridiaceous parasites of phanerogams. XIX. A Physoderma on Eurasian water milfoil (Myriophyllum spicatum). Amer. J. Bot. 61: 174-180.

, AND R. M. JoHNs. 1959. Observations on chytridiaceuus parasites of phanerogams. IX. Epibiotic sporangial stages of Physoderma collected in the field. Arch. Microbiol. 34: 93-102.

, AND M. S. SAunders. 1974. Observations on chytridiaceous parasites of phanerogams. XXII. A Physoderma on Ranunculus septentrionalis Poir. Arch. Microbiol. 100: 41-50. 